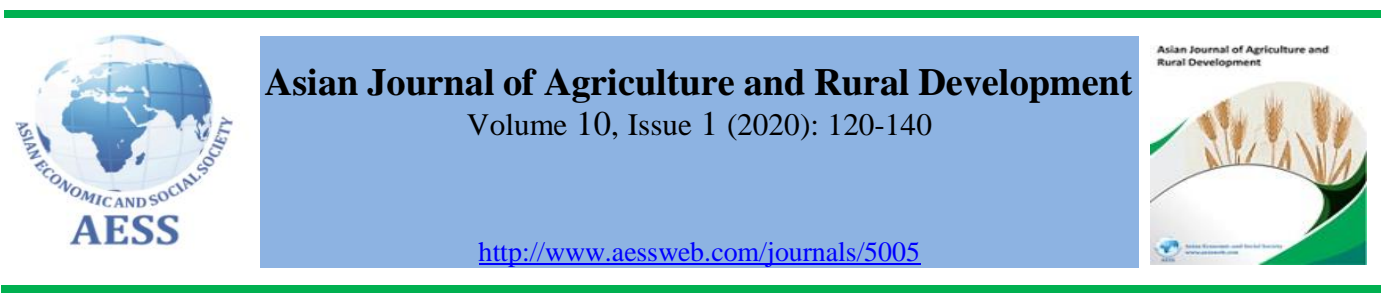

\title{
HOUSEHOLD FOOD INSECURITY AND NUTRITION STATUS: IMPLICATIONS FOR CHILD'S SURVIVAL IN SOUTH-WESTERN NIGERIA
}

Rufus B. Department of Sociology, Federal University Oye-Ekiti, Ekiti State, Akindola Nigeria

Boluwaji56@gmail.com

\section{ARTICLE HISTORY:}

Received: $23-$ Dec-2019

Accepted: 03-Mar-2020

Online Available: 26-Mar2020

\section{Keywords:}

Food security,

Child survival,

Nutrition status,

Vulnerability,

Mortality

\begin{abstract}
This study investigated the relationship between household food insecurity and nutrition status with a focus on the implications for child survival. Data were collected on 746 women of child-bearing age (15 - 49 years) in five states in south western Nigeria. The study finds that household food security increased with income and education. The findings show that child survival is not only about improving nutrition status in the household or improving household food security, but also activities that mothers undertake to enhance child survival.
\end{abstract}

\section{Contribution/ Originality}

This study is important in that information on the effects of household food insecurity will benefit policy makers who are currently interested in strategies for improving household food availability, accessibility and safety. The study will also bring the current information about the most vulnerable group of people in the household, "the very young ones".

DOI: 10.18488/journal.1005/2020.10.1/1005.1.120.140

ISSN (P): 2304-1455/ISSN (E):2224-4433

How to cite: Rufus B. Akindola (2020). Household food insecurity and nutrition status: implications for child's survival in South-Western Nigeria. Asian Journal of Agriculture and Rural Development, 10(1), 120-140.

(C) 2020 Asian Economic and Social Society. All rights reserved. 


\section{INTRODUCTION}

\subsection{Background of the study}

At the dawn of the new millennium, world leaders under the auspices of the United Nations pledged towards attacking the challenges of poverty; illiteracy; hunger; unsafe-water; diseases; urban and environmental degradation, within the time frame of 2000 and 2015 (Andohol, 2012). One of the major sustainable development goals in the countries of Africa is to improve children's health in the region. However, these goals are far from being achieved. The state of undernourishment in Africa is far above the experience of other developing regions. Studies have shown that a larger proportion of the African population suffers from starvation. Since 1990, food availability per capita in Sub-Saharan Africa has declined by 3 per cent (Ojogho, 2010). Reducing the risk of food insecurity is a major challenge confronting Africa today. Addressing this challenge, therefore, involves addressing short-term risks such as the recent economic crisis and volatility in food prices, and addressing long-term risks of chronic under nutrition (Harttgen and Klasen, 2010). These authors further argue that when there are more resources at the household level, the ability of the household members to acquire more calories and parents to invest more in the nutrition and health of their children is guaranteed.

Moreover, there has been a persistent increase in the level of food insecurity because extreme poverty remains on the increase and does not correspond with the soaring prices of food items. Though as Barrett and Lentz (2010) has suggested, the relationship between poverty and food insecurity is complex and bidirectional. Furthermore, studies have demonstrated that food insecurity results in malnutrition and ultimately propels ill health and lethargy, which eventually traps its victims in a cycle of poverty (Thomas and Strauss, 1997). In turn, poverty contributes to poor nutrition and health (Barrett and Lentz, 2010). It has been reported that over the decades, researchers found that early experience of food insecurity can have a lasting impact on people's lives, including children. Specifically, according to Chilton et al. (2007), studies of the first three years of life show a strong link among investments in primary education, maternal-child attachment and nurturance, and more creative nutrition initiatives on breaking the cycle of poverty.

Arguably, food insecurity can affect a young child's development and learning potential which can result in the continuity of poverty that is rolled-over to another generation (Chilton et al., 2007; Barrett and Lentz, 2010). It was also reported that increase in food prices resulted in at least 50 million more people becoming hungry globally in 2008 (FAO, 2008). Invariably, this food crisis may have negative impacts on human development in four ways: increasing poverty and inequality; worsening nutrition; reduction in utilization of education and health services, and depletion of the productive assets of the poor globally (Compton et al., 2010).

Even before the food crisis, GPF (2008) reported that an estimated 70\% of the world's hungry were women and girls. Accordingly, vulnerable groups, such as young children and pregnant women, are now at risk of becoming permanently malnourished; irreversibly impacting the next generation. Women are also more vulnerable to poverty, with less access to credit, property rights, education, training, good jobs, and farm inputs such as fertilizer and extension services, compared to men, making them one of the hardest hit groups in times of crisis (GPF, 2008). For example, ILO (2006) asserts that women own less than $15 \%$ of land worldwide and make up some $60 \%$ of the world's working poor, people who work but do not earn enough to lift themselves above the $\$ 1$ per day poverty line.

\subsection{Statement of the problem}

Malnutrition has remained a problem of public health importance in contemporary Nigeria despite the various interventions in the past two decades. According to Erhabor and Erhabor (2016), morbidity and mortality amongst Nigerian children can be attributed to the inability of households 
to secure food. Specifically, there is an increase in the prevalence level of Protein-Energy Malnutrition (PEM) and micronutrient deficiencies (Abubakar et al., 2017). Household food insecurity, as Cordeiro et al. (2007) suggest, plays an important role in determining poor nutritional health, which affects the physical growth and development of the child. In other words, the nutrition status of children under-five years is a priority due to vulnerability and child survival concerns. Moreover, an understanding of the relationship between household food security and child nutrition status is important (Cordeiro et al., 2007). According to the authors, high food prices imply re-prioritization of resources to address the current situation both at household and national levels. This will affect the healthcare-seeking behaviour since most resources will be diverted into food purchases. Also, compliance with taking drugs could be compromised, especially for medicines that required food before consumption. The number of malnourished children under five will increase. Reports show that, of the world's undernourished children, $80 \%$ live in 20 countries; 9 of these are in sub-Sahara Africa. About 200 million Africans are hungry and malnourished, including 31 million under-age five. About $35 \%$ of under-age five mortality is attributed to under-nutrition (Chaudhary et al., 2016).

\subsection{Objective of the study}

The general objective of this study was to examine the effects of household food security on child nutrition status, and the implications for child survival in South-Western Nigeria. The specific objective was to determine the socioeconomic factors associated with household food security and examine the impact of household food insecurity on nutrition status.

\section{REVIEW OF LITERATURE}

Food is the most basic need and necessity for human survival; and it is done through qualitative feeding behaviour. The feeding behaviour and access to the appropriate quantity and quality of food are essential components of optimal nutrition status for children (Ijarotimi and Odeyemi, 2011). The term food security has been identified in various ways. The World Bank, for example, defined food security as access by all people at all times to enough food for active and healthy life (Ojogho, 2010). Food insecurity, in turn, refers to limited or uncertain physical and economic access to secure sufficient quantities of nutritionally adequate and safe food in socially acceptable ways to allow household members to sustain active and healthy living (FAO, 1996). Child development in this context relates to health, anthropometric and academic performance of the child.

The main goal of food security is for individuals to be able to obtain adequate food needed at all times and to be able to utilise the food to meet the body's needs. According to (Omonona and Agoi, 2007; Ojogho, 2010), food security has been defined to include food availability, food accessibility, utilisation and stability of food access as the elements. Food security indicates the availability of and access to food by those in needing. Furthermore, the authors argue that household food insecurity has led to hunger and malnutrition in most countries, including Nigeria while also influencing health and nutritional status of children. On the other hand, Ijarotimi and Odeyemi (2011) maintain that food insecurity has been found to be the main factor causing poor feeding habits and protein-energy malnutrition among children. For example, findings from a study by Jyoti et al. (2005) in the United States confirm that food insecurity over time related to changes in reading and mathematics test performance, weight and body mass index, healthy social skills in children.

The concern for food security and nutritional well-being in an economy is predicted by the role of the human element in economic development. This shows why at national level, food is of economic and political significance, especially in issues that relate to promoting peace and stability among the populace. The socio-economic characteristics and resources of individual household have been identified as basic factors influencing the food security status of households. Worldwide, 
to 852 million men, women, and children are chronically hungry due to extreme poverty while up to 2 billion people lack food security intermittently due to varying degree of poverty (Ojo and Adebayo, 2012).

\subsection{Concern for food security in Nigeria}

The Federal Government of Nigeria (FGN) has played a major role in attempts to ensure food security at the national level in the country. Ojo and Adebayo (2012) indicate that these attempts have taken the form of implementing several food related schemes at the national level. According to these authors, the early 1970s marked a period of massive importation of rice, which could not solve the problem of food insecurity. The Operation Feed the Nation scheme implemented in 1976, for example, did not achieve much in solving the problem of hunger in the nation, whilst the Green Revolution scheme implemented in 1979 was just a mere change of name with little impact. Also, the Directorate of Food, Roads and Rural Infrastructure designed to improve national food production was a failure, as the program was engulfed in corruption that marred an impact (Ojo and Adebayo, 2012; Andohol, 2012). Moreover, much investment was made in agriculture during 1999-2007. Reports, however, showed that little has been achieved regarding food security in Nigeria. Also the level of importation in the country has remained very high for various food items.

Additionally, several international agencies have provided assistance to Nigeria, both at the federal and state levels, to boost agriculture in the nation. These include the World Bank, Food and Agricultural Organisation, United States Agency for International Development and International Fund for Agricultural Development. However, the attending problem of unstable policies as new government assumes office, the perception that agriculture is an occupation for the illiterate, corruption, low remuneration on farm produces, etc., have brought about the low level of achievement in the national food security (Ojo and Adebayo, 2012; Andohol, 2012).

\subsection{Conceptual framework}

This conceptual framework was adopted by Mosley and Chen in 1984 to explain the mechanism through which various modified proximate determinants operate to affect child survival in the study area (Mosley and Chen, 1984). The proximate determinants model was originally developed to study factors affecting child mortality, and is based on the idea that all social and economic determinants of child mortality operate through a set of biological or proximate determinants to affect a child's probability of survival. The framework model is a combination of social, economic, biological and medical explanations of child survival. Mosley and Chen (1984) group the proximate determinants into five categories, namely, maternal factors (mother's age and occupation); environmental contamination (routes of infection); nutrient deficiency; injury; and personal illness control (preventive and curative care).

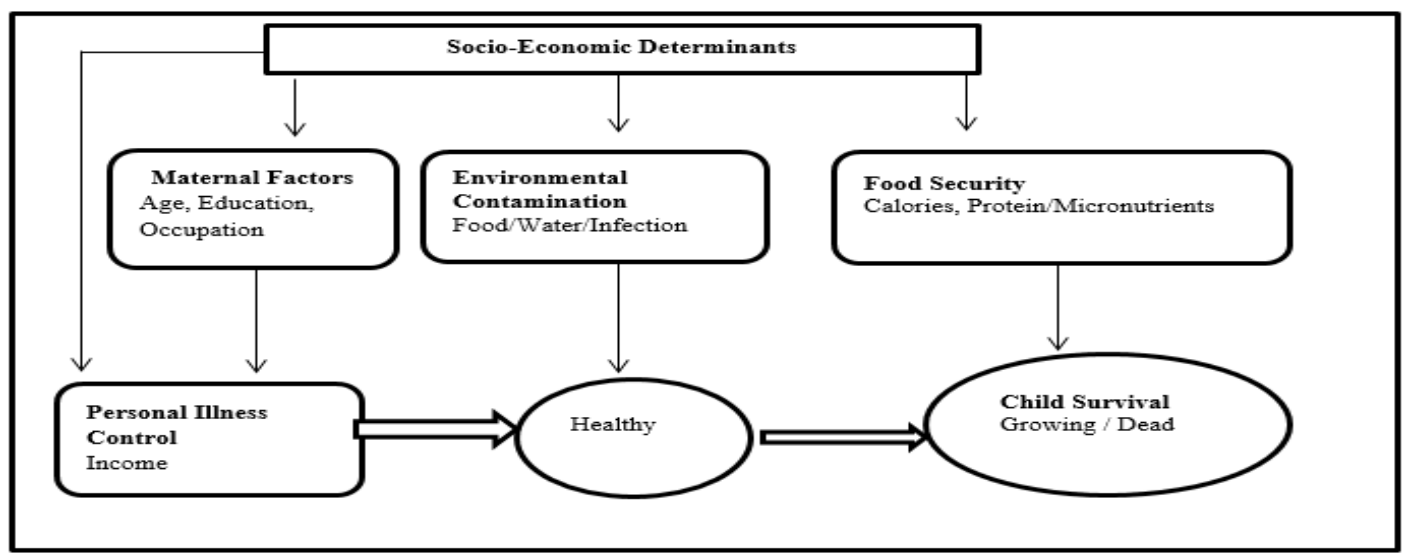

Figure 1: The mosley-chen framework-proximate determinants of child survival 
Food security is a broad and multi-dimensional concept. It relates to access to adequate food for a healthy life. That is, access to available food and adequate nutrient intake for sustainable health (Olagunju et al., 2012). Empirical studies show a strong relationship between household food security to household income and asset (or wealth) status. Empirical studies have also shown that low-income households are more likely to suffer food shortages than wealthier households. Poor households spend more on food, which constitutes a larger per cent of their spending, making them relatively more vulnerable to the impacts of food price inflation. This relationship between a household's food security status and its purchasing power, according to Aliber (2009), RomerLovendal and Knowles (2006), is far from static; it changes over time. All other factors remaining constant, changes in income alter the quantity and quality of food purchased and consumed. Price movements of food and non-food items also affect the ability to buy food.

Food security at the household level is a subset of the national level. That is, the ability of all individuals and households to have access to sufficient food either by producing it themselves or by generating sufficient income to demand it. Omonona and Agoi (2007) argue that food availability is a function of the combination of domestic food stocks, commercial food imports, food aid, and domestic food production, as well as the underlying determinants of each of these factors. Furthermore, the authors believe that accessibility is determined by the resource endowment of the household which defines the set of productive activities they can pursue in meeting their income and food security objectives. In this case, food utilization, which is typically reflected in the nutritional status of an individual, is determined by the quantity and quality of dietary intake, general childcare and feeding practices, along with health status and its determinants. Poor child care and feeding practices, inadequate access to, or the poor quality of health services is also major determinants of poor health and nutrition Omonona and Agoi (2007).

\section{MATERIAL AND METHODS}

\subsection{Study area}

Nigeria lies between $4^{\circ} 16^{\prime}$ " 1 and $13^{\circ} 0^{\prime} 53^{\prime}$ and between $20^{\circ} 40^{\prime} 1^{\prime \prime}$ and $14^{\circ} 04^{\prime} 11^{\prime \prime}$ eaast. As NBS (2010) shows, the country is in the West African sub-region and shares borders with Niger Republic in the north, Chad in the Northeast, Cameroon in the east, and Benin Republic in the West. To the south, Nigeria is bordered approximately by 800 kilometers of the Atlantic Ocean, stretching from Badagry in the west to the Rio del Rey in the East (NBS, 2010). With a total land area of $923.768 \mathrm{~km}$ square kilometers, Nigeria is the fourth largest in Africa. The country has a projected population of 170 million and life expectancies are around 50 years. Nigeria is an ethnically and religiously diverse country with over 250 ethnic groups (Akindola and Ehinomen, 2017). The country, according to the authors, is divided into six geo-political zones. This study was based in south-western Nigeria, comprising Oyo, Ekiti, Osun, Ondo, Ogun, and Lagos States. Most of the people living in the south-west are Yorubas. There are both Christians and Muslims in the region.

\subsection{Data collection}

Open ended questionnaire was developed for the survey of households. The questionnaire contained four modules (sections) on which data and information were collected. The first module contained questions on the socioeconomic characteristics of respondents, including age, income, occupation, marital status, education, etc. The second module contained questions relating to food security in the respondent household, including frequency of skipping meals, if at all; eating less than three square meals a day; the type of food eaten; whether children ate balanced meal; etc. The third module of the questionnaire contained questions to collect information relating to the nutrition status of the respondent household, including nutritional intensity of meals, frequency of consumption of fruits and vegetables, food advertisement, etc. The last fourth module of the questionnaire contained questions relating to child survival in a respondent household. These 
included frequency of attending antenatal before delivery, adherence to recommended dietary intake during pregnancy, breast-feeding, etc.

The questionnaires were administered mainly to women randomly selected from 192 communities across 75 local government areas in five South Western States Nigeria. Table 1 displays the distribution of the respondents across the five states covered. The five states were Ekiti, Ogun, Ondo, Osun, and Oyo states. Among the five states, Ekiti has the largest number of randomly selected respondents, representing $287(38.5 \%)$ of the total respondents. This was followed by Ondo state with around a third of the total respondents $261(35.0 \%)$ whilst Osun respondents were $75(10.1 \%)$ and Oyo has the smallest number of respondents at around $4 \%$. The women respondents were those who gave their consent to have their information used in the research. Also, collection of data focused on the local government areas which have been divided into enumeration areas by the National Population Commission (NPC, 2006). Out of a total of 762 questionnaires that were randomly administered, 16 of them were later dropped; comprising 13 questionnaires used for pretest, 2 respondents who refused consent to use their information for the research, and the remaining one questionnaire which was returned uncompleted. Overall, data comprised $n=746$ respondents with complete data and information.

Table 1: Distribution of respondents across the states in south-west Nigeria

\begin{tabular}{cc}
\hline Distribution of respondents across the five states & Number of respondents (\%) \\
\hline Ekiti & $303(39.8)$ \\
Ogun & $90(11.8)$ \\
Ondo & $261(34.3)$ \\
Osun & $75(9.8)$ \\
Oyo & $33(4.3)$ \\
Total & $762(100)$ \\
\hline
\end{tabular}

Source: Authors' calculation from survey data (2018)

\section{RESULTS}

\subsection{Socio-economic characteristics of the respondents}

Table 2 presents the socioeconomic characteristics of the respondents. The table shows the name of variables, the number of observation or data points observed $(\mathrm{N})$, mean, standard deviation (std), minimum ( $\min )$ and maximum (max). For ease of understanding, the mean or average figures for the categorical variables (e.g. marital status) are interpreted in percentage terms.

Table 2: Socio-demographic and economic characteristics of respondents

\begin{tabular}{lcccc}
\hline Variable & Mean & Std & Min & Max \\
\hline $\mathrm{N}=746$ & & & & \\
Age & 41.432 & 15.015 & 15 & 88 \\
Marital Status & & & & \\
Single & 0.083 & 0.276 & 0 & 1 \\
Married & 0.786 & 0.411 & 0 & 1 \\
Divorced & 0.064 & 0.246 & 0 & 1 \\
Widow/widower & 0.067 & 0.25 & 0 & 1 \\
Education Level & & & & \\
Secondary & 0.015 & 0.121 & 0 & 1 \\
modern school & 0.004 & 0.063 & 0 & 1 \\
OND & 0.055 & 0.228 & 0 & 1 \\
Postgraduate & 0.016 & 0.126 & 0 & 1 \\
Primary & 0.119 & 0.324 & 0 & 1 \\
\hline
\end{tabular}




\begin{tabular}{|c|c|c|c|c|}
\hline Senior Secondary & 0.312 & 0.464 & 0 & 1 \\
\hline Student & 0.012 & 0.109 & 0 & 1 \\
\hline Teacher Education & 0.109 & 0.311 & 0 & 1 \\
\hline Uneducated & 0.064 & 0.246 & 0 & 1 \\
\hline University/HND & 0.294 & 0.456 & 0 & 1 \\
\hline \multicolumn{5}{|l|}{ Monthly income group } \\
\hline 0 - N10000 (0 - 27 USD) & 0.2 & 0.4 & 0 & 1 \\
\hline 10001 - N20000 (28 - 54 USD) & 0.2 & 0.4 & 0 & 1 \\
\hline 20001 less than N30000 (55 - 82 USD) & 0.153 & 0.36 & 0 & 1 \\
\hline 30001 less than N40000 (83 - 109 USD) & 0.084 & 0.278 & 0 & 1 \\
\hline 40001 less than N50000 (110 - 136 USD) & 0.133 & 0.339 & 0 & 1 \\
\hline 50001 less than N750000 (137 - 204 USD) & 0.084 & 0.278 & 0 & 1 \\
\hline 75001 and above (204 USD and above) & 0.046 & 0.209 & 0 & 1 \\
\hline Declined \& don't know & 0.101 & 0.301 & 0 & 1 \\
\hline \multicolumn{5}{|l|}{ Occupation group } \\
\hline General business & 0.079 & 0.27 & 0 & 1 \\
\hline Trading & 0.275 & 0.447 & 0 & 1 \\
\hline Civil servant & 0.126 & 0.332 & 0 & 1 \\
\hline Professionals-Banker, Engineer, Nurse, etc. & 0.206 & 0.405 & 0 & 1 \\
\hline Teaching & 0.173 & 0.378 & 0 & 1 \\
\hline Student & 0.063 & 0.243 & 0 & 1 \\
\hline Farming only & 0.028 & 0.166 & 0 & 1 \\
\hline Housewife or unemployed & 0.05 & 0.217 & 0 & 1 \\
\hline \multicolumn{5}{|l|}{ Spouse has other wives } \\
\hline No & 0.519 & 0.5 & 0 & 1 \\
\hline Yes & 0.127 & 0.334 & 0 & 1 \\
\hline Don’t know & 0.008 & 0.089 & 0 & 1 \\
\hline Not applicable & 0.346 & 0.476 & 0 & 1 \\
\hline \multicolumn{5}{|l|}{ All wives live in the same household } \\
\hline Yes & 0.068 & 0.253 & 0 & 1 \\
\hline No & 0.166 & 0.373 & 0 & 1 \\
\hline Not answered & 0.056 & 0.231 & 0 & 1 \\
\hline Not applicable & 0.709 & 0.454 & 0 & 1 \\
\hline \multicolumn{5}{|l|}{ Ethnicity } \\
\hline Yoruba & 0.854 & 0.353 & 0 & 1 \\
\hline Igbo & 0.097 & 0.295 & 0 & 1 \\
\hline Hausa & 0.031 & 0.173 & 0 & 1 \\
\hline Other & 0.019 & 0.136 & 0 & 1 \\
\hline \multicolumn{5}{|l|}{ Religion } \\
\hline Christianity & 0.843 & 0.364 & 0 & 1 \\
\hline Islam & 0.133 & 0.339 & 0 & 1 \\
\hline Traditional religion & 0.008 & 0.089 & 0 & 1 \\
\hline Don’t know & 0.016 & 0.126 & 0 & 1 \\
\hline \multicolumn{5}{|l|}{ Household } \\
\hline Number of children & 3.109 & 1.563 & 1 & 10 \\
\hline Household size & 5.025 & 3.017 & 1 & 28 \\
\hline \multicolumn{5}{|l|}{ Age at first intercourse } \\
\hline At age 12 to 19 & 0.165 & 0.371 & 0 & 1 \\
\hline At age 20 to 25 & 0.509 & 0.500 & 0 & 1 \\
\hline At age $26 \&$ above & 0.196 & 0.397 & 0 & 1 \\
\hline Can't remember or don't know & 0.130 & 0.337 & 0 & 1 \\
\hline \multicolumn{5}{|l|}{ Age at first marriage } \\
\hline At age 12 to 21 & 0.189 & 0.392 & 0 & 1 \\
\hline
\end{tabular}




\begin{tabular}{lllll}
\hline At age 22 to 25 & 0.340 & 0.474 & 0 & 1 \\
At age 26 to 38 & 0.359 & 0.480 & 0 & 1 \\
Not applicable or don't know & 0.111 & 0.315 & 0 & 1 \\
\hline
\end{tabular}

Source: Authors' Calculations from Survey Data (2018)

As the table shows, the data were complete for all the 746 respondents. The average age of the respondents was a little over 41 years with the youngest being 15 years and the oldest 88 years. There was sufficient spread in the age of the respondents, suggesting there would be varied experience in the outcomes. Also, the majority of the total respondents $(71 \%)$ were females in reproductive age, 15-49 years. In terms of marital status, an overwhelming majority of the respondents (approx. 78.6\%) were married, which is consistent with the objectives of the study and a high probability of observing the outcomes in the sample. Moreover, an overwhelming majority of the respondents (approx. 79\%) were educated with at least secondary education and only about $6 \%$ were uneducated. This is not surprising given that Ekiti State is one of the most educated states in Nigeria. Obviously, the people are aware, as McMahon (2009), Psacharopoulos and Woodhall (1997) argue, that education has direct and wider returns to individual and immediate members of their family and society at large in terms of increased income, improved health and better decision making.

Additionally, the respondents were mainly low-income. Over half of the respondents (approx. $55.3 \%$ ) reported that they earn a monthly income of $\mathrm{N} 30,000$ or less, whilst $13 \%$ reported that they earn N50,000 and above. However, about $10 \%$ of the respondent declined to report their monthly income. Notice that the standard deviations for monthly income were generally greater than the mean values, suggesting potential for wide variations in income, hence the possibility of underreporting their income. Also, the respondents varied widely in terms of occupational status, as most of them reported they engage in different occupations. The majority of the respondents (approx. $27.5 \%$ ) were traders, approx. $13 \%$ civil servants, approx. $17 \%$ teachers, approx. $21 \%$ professionals, whilst only $5 \%$ were housewives or unemployed. Over half of the respondents (approx. 52\%) reported that their spouse has no other wives. Amongst these, only a few (approx. 6.8\%) reported that all the wives live in the same household. In terms of ethnicity and religion, an overwhelming majority of respondents were from the Yoruba ethnic group (approx. 85.4\%) and was Christian (approx. $84.3 \%$ ).

Moreover, the average household of the respondents has small families, with three numbers of children in the household on average and household size of about five. However, there were some large families as large as 10 number of children. Finally, a majority of the respondents (approx. $51 \%$ ) reported that they had first intercourse between 20 and 25 years of ages, whilst over a third of them (approx. 36\%) got married between 26 and 38 years of age. Overall, the socioeconomic characteristics of the respondents were generally consistent with the objectives of the study, particularly in terms of age, education level, income, and household circumstances. In the analysis section, the extent to which these characteristics were associated with household food security is further examined. It must be emphasised that Child malnutrition is still one of the most serious health problems in countries in sub-Saharan Africa and South Asia, According to Shinsugi et al. (2015), it is estimated that nearly 3.1 million children die annually either directly or indirectly as a result of malnutrition, and approximately 165 million children are affected by chronic restriction of potential growth. 
Table 3: Household food security

\begin{tabular}{|c|c|c|c|c|}
\hline Variable & Mean & $\overline{\text { Std }}$ & Min & $\operatorname{Max}$ \\
\hline \multicolumn{5}{|l|}{ Skipped meals in the last 12 months } \\
\hline Yes & 0.503 & 0.500 & 0 & 1 \\
\hline No & 0.489 & 0.500 & 0 & 1 \\
\hline Don’t know & 0.008 & 0.089 & 0 & 1 \\
\hline \multicolumn{5}{|l|}{ Frequency of skipping meals } \\
\hline Almost every month & 0.437 & 0.496 & 0 & 1 \\
\hline Some months, not every & 0.133 & 0.339 & 0 & 1 \\
\hline Only 1 or 2 months & 0.012 & 0.109 & 0 & 1 \\
\hline Don't know & 0.012 & 0.109 & 0 & 1 \\
\hline Not applicable & 0.406 & 0.491 & 0 & 1 \\
\hline \multicolumn{5}{|l|}{ Ate less than expected in last 12 months } \\
\hline Yes & 0.424 & 0.494 & 0 & 1 \\
\hline No & 0.531 & 0.499 & 0 & 1 \\
\hline Don't know & 0.046 & 0.209 & 0 & 1 \\
\hline \multicolumn{5}{|l|}{ Hungry but not enough to eat } \\
\hline Yes & 0.391 & 0.488 & 0 & 1 \\
\hline No & 0.564 & 0.496 & 0 & 1 \\
\hline Don't know & 0.044 & 0.206 & 0 & 1 \\
\hline \multicolumn{5}{|l|}{ Few low-cost food to feed child } \\
\hline Often true & 0.127 & 0.334 & 0 & 1 \\
\hline Sometimes true & 0.576 & 0.494 & 0 & 1 \\
\hline Never true & 0.277 & 0.448 & 0 & 1 \\
\hline Don't know & 0.019 & 0.136 & 0 & 1 \\
\hline \multicolumn{5}{|l|}{ Unaffordable balanced meal for child } \\
\hline Often true & 0.118 & 0.323 & 0 & 1 \\
\hline Sometimes true & 0.487 & 0.500 & 0 & 1 \\
\hline Never true & 0.367 & 0.482 & 0 & 1 \\
\hline Don't know & 0.028 & 0.166 & 0 & 1 \\
\hline \multicolumn{5}{|l|}{ Child not eating enough food } \\
\hline Often true & 0.094 & 0.292 & 0 & 1 \\
\hline Sometimes true & 0.413 & 0.493 & 0 & 1 \\
\hline Never true & 0.458 & 0.499 & 0 & 1 \\
\hline Don't know & 0.035 & 0.184 & 0 & 1 \\
\hline \multicolumn{5}{|l|}{ Child go hungry when there is no more food } \\
\hline Yes & 0.273 & 0.446 & 0 & 1 \\
\hline No & 0.643 & 0.479 & 0 & 1 \\
\hline Don't know & 0.083 & 0.276 & 0 & 1 \\
\hline \multicolumn{5}{|l|}{ Frequency of unbalanced meal in household } \\
\hline A lot & 0.094 & 0.292 & 0 & 1 \\
\hline Sometimes & 0.665 & 0.472 & 0 & 1 \\
\hline Never & 0.241 & 0.428 & 0 & 1 \\
\hline \multicolumn{5}{|l|}{ Description of food eaten in household } \\
\hline Enough of all kinds of food we want to eat & 0.339 & 0.474 & 0 & 1 \\
\hline Enough but not always for all kinds of food & 0.449 & 0.498 & 0 & 1 \\
\hline Sometimes not enough to eat & 0.153 & 0.36 & 0 & 1 \\
\hline Often not enough to eat & 0.023 & 0.149 & 0 & 1 \\
\hline Don't know & 0.036 & 0.187 & 0 & 1 \\
\hline \multicolumn{5}{|l|}{ Composite measure of food security } \\
\hline Household food security index & 18.282 & 6.678 & 4 & 29 \\
\hline
\end{tabular}

Source: Author's calculations from survey data 
About half of the respondents $(50.3 \%)$ reported that they skipped meals in the last 12 months, and the majority among this group of respondents (approx. 44\%) also reported that they skipped meals almost every month. Also, a majority of the respondents (approx. 58\%) reported that they relied upon only a few kinds of low-cost food to feed their children whenever they ran out of money to buy food. Additionally, a majority of the respondents (approx. 60.5\%) reported that it is often or sometimes true that their children could not eat a balanced meal, as they could not afford it. It is imperative to state that physical inactivity and an unbalanced diet, as postulated by Vandevijvere et al. (2015), are major risk factors for chronic diseases in both childhood and adulthood.

A majority of the respondents (53\%) reported that they did not eat less than they had expected in the last 12 months. Also, when asked whether they were very hungry but did not eat because they had not enough money for food in the last 12 months, a majority of them (56.4\%) reported that this was not the case. Moreover, a majority, (approx. 64.3\%), reported that their children did not have to go hungry whenever food was not enough. Nevertheless, the respondents appear to be divided regarding whether their children were not eating enough food in the last 12 months. Whereas a majority of them (approx. 50.7\%) reported that it is often or sometimes true that they did not, approx. $56 \%$ also reported that it is not true that they did.

At the household level, over two-thirds majority of the respondents (approx. 66.5\%) reported that they sometimes eat an unbalanced meal In providing an overall description of the food eaten at the household level, over a third (approx. 34\%) reported that they have both enough of all kinds of food they want to eat, whilst $45 \%$ of the respondents reported that though they have enough food to eat, but not always so for all kinds of food. The descriptive statistics of household food security variables are mixed. Whilst some variables indicated that the majority of the respondent household were insecure, others provided an indication of moderately food secured households. Nevertheless, household food insecurity, as asserted by Drammeh et al. (2019), is increasingly deemed to be a global health problem, especially in Sub-Saharan Africa. In this case, tackling food insecurity means that food should always remain available and accessible to all individuals throughout the life course (Drammeh et al., 2019).

Finally, using the response options to derive an aggregate measure, the overall household food security score was 18.28 on average, ranging between the lowest score of 4 and highest at 29 . Comparing to the maximum score at 33, these figures suggest that just a little over half of the respondent households (approx. 55.4\%) were food secured. Thus, whereas there were a few extremely food insecure households, some were highly food secured. Indeed only 48 or approx. $6 \%$ of the respondents scored above average on the household food security index.

\subsection{Nutrition status}

Table 4 presents the summary statistics of the variables for measuring nutrition status of the respondent households. As the table shows, an overwhelming majority of the last child of the respondents (approx. 75\%) was 24 years or less. This is consistent with examining the nutrition status and child survival in the sample.

Table 4: Nutrition status

\begin{tabular}{lccccc}
\hline Variables & $(\%)$ & Mean & Std. & Min & Max \\
\hline Age of last child & & & & & \\
Less than 12 months & 40.1 & 0.401 & 0.490 & 0 & 1 \\
$13-24$ months & 34.9 & 0.349 & 0.477 & 0 & 1 \\
Above 24 months & 18.2 & 0.182 & 0.386 & 0 & 1 \\
Don't know & 6.8 & 0.068 & 0.253 & 0 & 1 \\
Frequency of eating & & & & & \\
Once daily & 2.4 & 0.024 & 0.154 & 0 & 1 \\
\hline
\end{tabular}




\begin{tabular}{|c|c|c|c|c|c|}
\hline Twice daily & 33.4 & 0.334 & 0.472 & 0 & 1 \\
\hline Three times daily & 47.3 & 0.473 & 0.5 & 0 & 1 \\
\hline All through the day & 15.7 & 0.157 & 0.364 & 0 & 1 \\
\hline Other & 1.2 & 0.012 & 0.109 & 0 & 1 \\
\hline \multicolumn{6}{|c|}{ Meals are nutritious intense } \\
\hline Yes & 58.2 & 0.582 & 0.494 & 0 & 1 \\
\hline No & 38.6 & 0.386 & 0.487 & 0 & 1 \\
\hline Don't know & 3.2 & 0.032 & 0.177 & 0 & 1 \\
\hline \multicolumn{6}{|c|}{ Frequency of taking milk } \\
\hline Everyday & 10.3 & 0.103 & 0.304 & 0 & 1 \\
\hline Twice a week & 27.3 & 0.273 & 0.446 & 0 & 1 \\
\hline Three times a week & 22.5 & 0.225 & 0.418 & 0 & 1 \\
\hline Few days in a month & 37.8 & 0.378 & 0.485 & 0 & 1 \\
\hline Other & 2.0 & 0.02 & 0.14 & 0 & 1 \\
\hline \multicolumn{6}{|c|}{ Frequency of taking tea/coffee } \\
\hline Everyday & 10.5 & 0.105 & 0.306 & 0 & 1 \\
\hline Twice a week & 22.7 & 0.227 & 0.419 & 0 & 1 \\
\hline Three times a week & 21.4 & 0.214 & 0.411 & 0 & 1 \\
\hline Few days in a month & 38.2 & 0.382 & 0.486 & 0 & 1 \\
\hline Other & 7.2 & 0.072 & 0.259 & 0 & 1 \\
\hline \multicolumn{6}{|c|}{ Frequency of taking fruits } \\
\hline Everyday & 18.8 & 0.188 & 0.391 & 0 & 1 \\
\hline Twice a week & 24 & 0.24 & 0.427 & 0 & 1 \\
\hline Three times a week & 30.2 & 0.302 & 0.459 & 0 & 1 \\
\hline Few days in a month & 18.4 & 0.184 & 0.387 & 0 & 1 \\
\hline Other & 8.7 & 0.087 & 0.282 & 0 & 1 \\
\hline \multicolumn{6}{|c|}{ Frequency of taking irish/white potatoes } \\
\hline Everyday & 16.9 & 0.169 & 0.375 & 0 & 1 \\
\hline Twice a week & 28.3 & 0.283 & 0.451 & 0 & 1 \\
\hline Three times a week & 18.1 & 0.181 & 0.385 & 0 & 1 \\
\hline Few days in a month & 31.5 & 0.315 & 0.465 & 0 & 1 \\
\hline Other & 5.2 & 0.052 & 0.223 & 0 & 1 \\
\hline \multicolumn{6}{|c|}{ Frequency of taking vegetables } \\
\hline Everyday & 22.4 & 0.224 & 0.417 & 0 & 1 \\
\hline Twice a week & 35.8 & 0.358 & 0.48 & 0 & 1 \\
\hline Three times a week & 18 & 0.18 & 0.384 & 0 & 1 \\
\hline Few days in a month & 20.4 & 0.204 & 0.403 & 0 & 1 \\
\hline Other & 3.5 & 0.035 & 0.184 & 0 & 1 \\
\hline \multicolumn{6}{|c|}{ Frequency of taking fruit juice } \\
\hline None & 13.9 & 0.139 & 0.347 & 0 & 1 \\
\hline Everyday & 3.1 & 0.031 & 0.173 & 0 & 1 \\
\hline Twice a week & 12.5 & 0.125 & 0.331 & 0 & 1 \\
\hline Three times a week & 9.1 & 0.091 & 0.288 & 0 & 1 \\
\hline Few days in a month & 52.5 & 0.525 & 0.5 & 0 & 1 \\
\hline Other & 8.8 & 0.088 & 0.284 & 0 & 1 \\
\hline \multicolumn{6}{|c|}{ Familiarity with nutrition ad } \\
\hline Yes & 83.4 & 0.834 & 0.373 & 0 & 1 \\
\hline No & 16.6 & 0.166 & 0.373 & 0 & 1 \\
\hline \multicolumn{6}{|c|}{ If yes, where were you familiar } \\
\hline Television & 48.8 & 0.488 & 0.5 & 0 & 1 \\
\hline Radio & 22.7 & 0.227 & 0.419 & 0 & 1 \\
\hline Newspaper & 2.3 & 0.023 & 0.149 & 0 & 1 \\
\hline Friends & 8 & 0.08 & 0.272 & 0 & 1 \\
\hline
\end{tabular}




\begin{tabular}{lccccc}
\hline Other & 2 & 0.02 & 0.14 & 0 & 1 \\
Not applicable & 16.2 & 0.162 & 0.369 & 0 & 1 \\
Income affects choice of food intake & & & & & \\
Yes & 51.9 & 0.519 & 0.5 & 0 & 1 \\
No & 48.1 & 0.481 & 0.5 & 0 & 1 \\
Spouse influences choice of food intake & & & & & \\
Yes & 39.4 & 0.394 & 0.489 & 0 & 1 \\
No & 60.6 & 0.606 & 0.489 & 0 & 1 \\
Coping strategy & & & & & \\
Eating less preferred food & 42.9 & 0.429 & 0.495 & 0 & 1 \\
Reduction or rationing & 37.3 & 0.373 & 0.484 & 0 & 1 \\
Beg for food or money to buy & 9.4 & 0.094 & 0.292 & 0 & 1 \\
Skipping meals within a day & 10.5 & 0.105 & 0.306 & 0 & 1 \\
Composite measure of nutrition status & & & & & \\
Nutrition status index & & 26.206 & 5.394 & 12 & 39 \\
\hline
\end{tabular}

Source: Author's calculations from survey data (2018)

A majority of the respondents (approx. 47.3\%) indicated that people in their household eat three times daily. Only $2.4 \%$ reported that their household eat once daily. A majority of the respondents (approx. 58.2) also reported that they eat nutritious intense meals. When the respondents were asked how often they drank milk and tea/coffee, a majority of them (approx. 37.8\%) and (approx. $38.2 \%$ ) reported that they do so only a few days in a month respectively. In terms of frequency of fruit and vegetables consumption, approx. $30.2 \%$ and approx. $35.8 \%$ of the respondents indicated that they did so three times a week and twice a week respectively. However, a majority of the respondents (approx. 52.5\%) reported being taking fruit juice only a few days in a month. Also, only around a third of the respondents (approx. 31.5\%) reported that they took Irish/white potatoes only a few days in a month.

When the respondents were asked about their familiarity with nutrition adverts, an overwhelming majority of them $(83.4 \%)$ reported that they did so, and this was mainly through radio and television (approx. 71\%). The respondents were also asked about possible influences on their household choice of food intake. The respondents were almost equally divided as to whether income affected their choice of food intake, as approx. 52\% reported that it did. However, a majority of the respondents (approx. 60.6\%) were of the view that their spouses did not influence their choice of food intake. On the question on how the respondents cope with a shortage of food, a majority of the respondents (approx. 43\%) indicated that they did so by eating less preferred food, whilst only $9 \%$ reported that they beg for food or money to eat. Finally, the response options were also used to derive an aggregate measure. The overall nutrition status score was 26.2 on average, ranging between the lowest score of 12 and highest at 39. The maximum score obtainable was 41 . The raw data showed that just about half of the respondents (approx. 52\%) scored above average on nutrition status.

\subsection{Child survival}

Table 5 presents the summary statistics of the variables for measuring child survival in respondent households. As the table shows, an overwhelming majority of the respondents (approx. 82\%) reported that they had their last child in a health care facility (i.e. health/maternity centre or general hospital). Only about $11.7 \%$ of them are reported having their child at home. Having a new born at a healthcare facility increases the chance of child survival. 
Table 5: Child survival

\begin{tabular}{|c|c|c|c|c|c|}
\hline Variable & $\%$ & Mean & Std. & Min & Max \\
\hline \multicolumn{6}{|c|}{ Where your last child was born } \\
\hline At home & 11.7 & 0.117 & 0.321 & 0 & 1 \\
\hline Health /maternity centre & 38.1 & 0.381 & 0.486 & 0 & 1 \\
\hline General hospital & 43.8 & 0.438 & 0.497 & 0 & 1 \\
\hline Teaching hospital & 6.4 & 0.064 & 0.246 & 0 & 1 \\
\hline \multicolumn{6}{|c|}{ No. of antenatal attended before delivery } \\
\hline Did not go for antenatal & 2 & 0.02 & 0.14 & 0 & 1 \\
\hline Only occasionally & 9.1 & 0.091 & 0.288 & 0 & 1 \\
\hline Less than 3 times & 9.4 & 0.094 & 0.292 & 0 & 1 \\
\hline 10 to 20 times & 15 & 0.15 & 0.357 & 0 & 1 \\
\hline 20 to 40 times & 3.5 & 0.035 & 0.184 & 0 & 1 \\
\hline All appointed days & 24 & 0.24 & 0.427 & 0 & 1 \\
\hline Don't know & 37 & 0.37 & 0.483 & 0 & 1 \\
\hline \multicolumn{6}{|c|}{ Adherence to recommended dietary intake when preg } \\
\hline Yes & 72.9 & 0.729 & 0.445 & 0 & 1 \\
\hline No & 27.1 & 0.271 & 0.445 & 0 & 1 \\
\hline \multicolumn{6}{|c|}{ Child first receive breast-milk when born } \\
\hline Immediately & 70.8 & 0.708 & 0.455 & 0 & 1 \\
\hline Following day to third & 26.4 & 0.264 & 0.441 & 0 & 1 \\
\hline Much later & 2.8 & 0.028 & 0.166 & 0 & 1 \\
\hline \multicolumn{6}{|c|}{ Child received anything else before breast-milk } \\
\hline Yes & 33.9 & 0.339 & 0.474 & 0 & 1 \\
\hline No & 66.1 & 0.661 & 0.474 & 0 & 1 \\
\hline \multicolumn{6}{|l|}{ What baby received } \\
\hline Water & 19.6 & 0.196 & 0.397 & 0 & 1 \\
\hline Pap & 5.4 & 0.054 & 0.225 & 0 & 1 \\
\hline Canned or baby milk & 7.9 & 0.079 & 0.27 & 0 & 1 \\
\hline Other & 1.1 & 0.011 & 0.103 & 0 & 1 \\
\hline Not applicable & 66.1 & 0.661 & 0.474 & 0 & 1 \\
\hline \multicolumn{6}{|c|}{ Baby received the first milk (Colostrums) } \\
\hline Yes & 87.4 & 0.874 & 0.332 & 0 & 1 \\
\hline No & 12.6 & 0.126 & 0.332 & 0 & 1 \\
\hline \multicolumn{6}{|c|}{ How did you feel for giving first milk } \\
\hline Happy, glad, good, better & 34.2 & 0.342 & 0.475 & 0 & 1 \\
\hline Painful & 52.7 & 0.527 & 0.5 & 0 & 1 \\
\hline Not applicable & 13.1 & 0.131 & 0.337 & 0 & 1 \\
\hline \multicolumn{6}{|c|}{ Child received other food/ liquid after birth } \\
\hline Yes & 62.1 & 0.621 & 0.486 & 0 & 1 \\
\hline No & 37.9 & 0.379 & 0.486 & 0 & 1 \\
\hline \multicolumn{6}{|c|}{ Other food/liquid received after birth } \\
\hline Baby milk only & 5.8 & 0.058 & 0.233 & 0 & 1 \\
\hline Baby milk and others & 22 & 0.22 & 0.414 & 0 & 1 \\
\hline Pap only & 9.9 & 0.099 & 0.299 & 0 & 1 \\
\hline Pap and others & 12.1 & 0.121 & 0.326 & 0 & 1 \\
\hline Water only & 9.5 & 0.095 & 0.294 & 0 & 1 \\
\hline Others-grape, lactogen, etc. & 2.8 & 0.028 & 0.166 & 0 & 1 \\
\hline Not applicable & 37.9 & 0.379 & 0.486 & 0 & 1 \\
\hline \multicolumn{6}{|l|}{ What was given the baby } \\
\hline Water & 26.3 & 0.263 & 0.44 & 0 & 1 \\
\hline Pap & 19 & 0.19 & 0.393 & 0 & 1 \\
\hline
\end{tabular}




\begin{tabular}{|c|c|c|c|c|c|}
\hline Canned milk/baby milk & 14.6 & 0.146 & 0.353 & 0 & 1 \\
\hline Other & 2.1 & 0.021 & 0.145 & 0 & 1 \\
\hline Not applicable & 37.9 & 0.379 & 0.486 & 0 & 1 \\
\hline \multicolumn{6}{|c|}{ At what age was other food/liquid given } \\
\hline One day - one week & 3.6 & 0.036 & 0.187 & 0 & 1 \\
\hline After one week - one month & 7.1 & 0.071 & 0.257 & 0 & 1 \\
\hline After one month - three & 29.2 & 0.292 & 0.455 & 0 & 1 \\
\hline After three month - six & 35.7 & 0.357 & 0.479 & 0 & 1 \\
\hline After six month - nine month & 19.4 & 0.194 & 0.396 & 0 & 1 \\
\hline After nine month - one year & 2.8 & 0.028 & 0.166 & 0 & 1 \\
\hline After one year & 1.7 & 0.017 & 0.131 & 0 & 1 \\
\hline Don't know/remember & 0.4 & 0.004 & 0.063 & 0 & 1 \\
\hline \multicolumn{6}{|c|}{ Special foods for mothers to produce more milk } \\
\hline Yes & 83.6 & 0.836 & 0.37 & 0 & 1 \\
\hline No & 16.4 & 0.164 & 0.37 & 0 & 1 \\
\hline \multicolumn{6}{|l|}{ Child ill 6 months before survey } \\
\hline Yes & 58 & 0.58 & 0.494 & 0 & 1 \\
\hline No & 42 & 0.42 & 0.494 & 0 & 1 \\
\hline \multicolumn{6}{|l|}{ Nature of illness } \\
\hline Malaria/fever & 29.5 & 0.295 & 0.456 & 0 & 1 \\
\hline Diahrrea & 11.3 & 0.113 & 0.316 & 0 & 1 \\
\hline Cough & 14.9 & 0.149 & 0.356 & 0 & 1 \\
\hline Anaemia & 2.4 & 0.024 & 0.154 & 0 & 1 \\
\hline Not applicable & 42 & 0.42 & 0.494 & 0 & 1 \\
\hline \multicolumn{6}{|l|}{ Sought medical attention } \\
\hline Yes & 50.5 & 0.505 & 0.5 & 0 & 1 \\
\hline No & 7.5 & 0.075 & 0.264 & 0 & 1 \\
\hline Not applicable & 42 & 0.42 & 0.494 & 0 & 1 \\
\hline \multicolumn{6}{|l|}{ Where sought medical attention } \\
\hline Medicine store & 7.9 & 0.079 & 0.27 & 0 & 1 \\
\hline Health/maternity & 18.9 & 0.189 & 0.392 & 0 & 1 \\
\hline General hospital & 27.7 & 0.277 & 0.448 & 0 & 1 \\
\hline Teaching hospital & 3.5 & 0.035 & 0.184 & 0 & 1 \\
\hline Not applicable & 42 & 0.42 & 0.494 & 0 & 1 \\
\hline \multicolumn{6}{|c|}{ Composite measure of child survival } \\
\hline Child Survival index & & 27.075 & 4.737 & 14 & 38 \\
\hline
\end{tabular}

Source: Author's calculations from survey data (2018)

Although a majority of the respondents reported that they could not really remember how many times they attended antenatal before delivery, approx. $24 \%$ of them reported that they attended all their appointed antenatal days, whilst only $2 \%$ reported that they did not go for antenatal before delivery. Moreover, an overwhelming majority of the respondents (approx. 73\%) adhered to the recommended dietary intake when they were pregnant. Additionally, approx. $71 \%$ of the respondents gave breast-milk to their child immediately after birth, whilst only approx. $3 \%$ did so much later. A majority of the respondents (approx. 66\%) did not give the child anything else before breast-milk. For those who reported that they gave anything else, a majority of them (approx. 20\%) gave only water. An overwhelming majority of the respondents (approx. 87.4\%) gave first milk (colostrum) to their child when they were born, though a majority of these respondents (approx. $53 \%$ ) found it painful. In addition to breast-milk, a majority of the respondents (approx. 62.1\%) also expressed that they gave other food/liquid to the child after birth. For these respondents, a majority of them (approx. 22\%) gave baby milk and others; such as water (approx. 26\%) and pap (19\%), which a majority (approx. 35.7\%) gave when the child was between three and six months. 
Moreover, an overwhelming majority of the respondents (approx. 83.6\%) believed that there are special foods which mothers could eat to produce more milk. As Katarzyna (2019) has rightly espoused, breastfeeding is a special period in the life of a woman and her baby. Accordingly, during the nursing period, the need for energy, nutrients and minerals increases. In this case, the daily diet of lactating women should consist mostly of complex carbohydrates as the author further suggests.

Child illness within the last six months will reduce the probability of child survival. A majority of the respondents $(58 \%)$ reported that their child was ill within six months before the survey. For these respondents, the nature of the illness was primarily malaria/fever (approx. 30\%), diarrhoea (approx. 11\%), and cough (approx. 15\%), and a majority of them (approx. 51\%) reported that they sought medical attention from a health care facility such as health/maternity centre (approx. 19\%) and a general hospital (approx. 28\%). Finally, the response options were also used to derive an aggregate measure for the overall child survival score. The overall child survival score was 27.1 on average, ranging between the lowest score of 14 and highest at 38 . The maximum score obtainable was 44 . The raw data showed that about half of the respondents (approx. 49\%) scored above the average score on the child survival index.

Table 6: Socioeconomic factors affecting household food security

\begin{tabular}{|c|c|}
\hline VARIABLES & Food security index \\
\hline Age & $-0.0139(0.0173)$ \\
\hline \multicolumn{2}{|l|}{ Marital status: Ref. Single } \\
\hline Married & $0.110(0.991)$ \\
\hline Divorced & $-0.402(1.518)$ \\
\hline Widow/widower & $-2.917(1.462)^{* *}$ \\
\hline \multicolumn{2}{|l|}{ Education level Ref. Uneducated } \\
\hline Primary & $-5.411(1.347)^{* * *}$ \\
\hline Modern school & $4.406(1.896)^{* *}$ \\
\hline Junior secondary & $-8.634(1.346) * * *$ \\
\hline Senior secondary & $-2.442(1.218)^{* *}$ \\
\hline OND & $-5.426(1.299) * * *$ \\
\hline Teacher education & $-0.140(1.346)$ \\
\hline University/HND & $0.0198(1.281)$ \\
\hline Postgraduate & $0.364(2.159)$ \\
\hline Student & $0.00322(2.283)$ \\
\hline \multicolumn{2}{|l|}{ Income: Ref. 0 - N10000 } \\
\hline $10000-20000$ & $-0.0317(0.785)$ \\
\hline $20001-30000$ & $-1.910(0.904)^{* *}$ \\
\hline $30001-40000$ & $-2.781(1.139)^{* *}$ \\
\hline $40001-50000$ & $-1.298(0.932)$ \\
\hline $50001-750000$ & $-1.752(1.139)$ \\
\hline 75001 and above & $-1.406(1.335)$ \\
\hline Not reported & $-1.911(0.996)^{*}$ \\
\hline \multicolumn{2}{|l|}{ Occupation, Ref. housewife/unemployed } \\
\hline General business & $-0.205(1.639)$ \\
\hline Trading & $-0.446(1.400)$ \\
\hline Civil servant & $2.391(1.528)$ \\
\hline Professional - banker, engineer, nurse, etc & $-1.715(1.471)$ \\
\hline Teaching & $1.152(1.512)$ \\
\hline Student & $-1.740(1.917)$ \\
\hline Farming only & $-1.639(1.780)$ \\
\hline Spouse has other wives & \\
\hline
\end{tabular}




\begin{tabular}{lc}
\hline Yes & $-1.714(0.850)^{* *}$ \\
All wives live in the same house & $1.504(0.855)^{*}$ \\
Yes & $-0.0538(0.788)$ \\
Ethnicity, Ref. Yoruba & $1.789(1.441)$ \\
Igbo & $-1.685(1.728)$ \\
Hausa & $-0.621(0.828)$ \\
Other & $-2.909(1.532)^{*}$ \\
Religion. Ref. Christianity & \\
Islam & $0.955(0.577)^{*}$ \\
Traditional religion & $1.738(0.798)^{* *}$ \\
Age at first intercourse. Ref. at age 12 to 19 & $1.072(0.637)^{*}$ \\
At age 20 to 25 & $0.634(0.737)$ \\
At age 26 \& above & $20.85(2.223)^{* * *}$ \\
Age at first marriage. Ref. at age 12 to 21 & 746 \\
At age 22 to 25 & 0.224 \\
At age 26 to 38 & \\
Constant & \\
Observations & \\
R-squared & \\
\hline
\end{tabular}

Note: Robust standard errors in brackets. The asterisks indicated level of significances; *** p $<0.01$, ** $\mathrm{p}<$ $0.05, * \mathrm{p}<0.1$. For categorical variables, the point estimates are interpreted in comparison to a reference group

Source: Author's calculations from survey data (2018)

As the table shows, age has no effect on household food security in this data. Widows/widowers were less likely than those that were single to be food secured and the effect was statistically significant at 5\% level. Other marital status has no effect on food security. Those with lower levels of education were highly significantly less likely to be food secured. Higher levels of education above OND, or being a student, have no effect on household food security. Those at relatively lower levels of income were significantly less likely to be food secured. The effects were statistically significant at 5\% level only for income levels between N20,000 to N40,000 (55 to 108 USD) per month. The remaining income groups have no effect on household food security. It appears that income is endogenous to other factors.

Occupational status of the individual has no effect on household food security. As expected, however, polygamous households (where the spouse has another wife) were less likely to be food secured. The effect is statistically significant at 5\% level. Where all wives live in the same house, the effect is statistically and marginally significant at $10 \%$ level. Ethnicity has no effect on household food security. Moreover, traditional religious households were significantly less likely to be food secured than Christian religious households. The effect is only marginally significant at the $10 \%$ level. In terms of early social relationships, food security increased progressively and in the level of statistical significance of the age range for which the respondent had the first intercourse. Those whose first intercourse was at age 20 and above were statistically and significantly more likely to be food secured than those of lesser age. However, those who got married between the age of 22 and 25 were marginally and significantly more likely to be food secured than those who got married at an earlier age.

In summary, the result of the income groups appears consistent with the literature which suggests that low-income households were more likely to suffer food shortages than wealthier households. However, the present study also shows that the income effect disappears after N40, 000 (55 USD) monthly incomes. This suggests that the income effect is less likely to be linear. 
Table 7: Estimation results of the probit and instrumental variable regressions

\begin{tabular}{lccc}
\hline Variables & $\begin{array}{c}\text { (1: Probit model) } \\
\text { Child ill last 6 months }\end{array}$ & $\begin{array}{c}\text { (2: IV model 1) } \\
\text { Child survival }\end{array}$ & $\begin{array}{c}\text { (3: IV model 2) } \\
\text { Child survival }\end{array}$ \\
\hline Household food security & $-0.0225(0.00701)^{* * *}$ & - & $0.171(0.0547)^{* * *}$ \\
Nutrition status & $-2.573(5.034)$ & $0.323(0.0940)^{* * * *}$ & - \\
Child ill last 6 months & - & $-4.405(0.340)^{* * *}$ & $-4.136(0.340)^{* * *}$ \\
Constant & $0.719(0.258)^{* * *}$ & $21.18(2.492)^{* * *}$ & $26.36(1.070)^{* * *}$ \\
Observations & 746 & 746 & 746 \\
R-squared & - & 0.041 & 0.313 \\
\hline
\end{tabular}

Note: Robust standard errors in brackets. The asterisks indicated levels of significance; $* * * \mathrm{p}<0.01, * * \mathrm{p}<$ $0.05, * \mathrm{p}<0.1$

In the probit model, child illness as a measure of child survival was negatively related to household food security score, and the effect was highly statistically significant at $1 \%$ level. This result suggests that the more food secure households were less likely to have their children illness in the last 6 months before the survey. However, the effect of nutritional status on child illness was statistically not different from zero. We did not find any effect because household food security and nutrition status were related, thereby creating endogeneity problem. The IV model in Models 2 and 3 solved the endogeneity problem.

In the IV model 2, the aggregate measure of household food security was a key instrument for nutrition status, other variables included were education level and income. As expected, child survival was strongly positively associated with nutrition status score, and the effect was highly statistically significant at $1 \%$ level. This result suggests that the chance of child survival increases with higher nutrition status. The coefficient on child illness was negative and highly statistically significant at $1 \%$ level, suggesting that child illness reduces the probability of child survival.

Using nutrition status as an instrument for household food security in Model 3, the probability of child survival also increased significantly with higher household food security score. The effect was highly statistically significant at $1 \%$ level. This result indicates that the more food secured a household is, the greater the chance of child survival, and the linkage is through the effect of household food security on nutrition status. On the other hand, the coefficient on child illness was negative and highly statistically significant at $1 \%$ level. This suggests that child illness reduces the probability of child survival and the more reason why it is argued in literature that under-5 child mortality continues to be an important public health problem and a serious challenge for developing countries. According to Hani (2011), most of the 8.1 million children who died before their fifth birthday in 2009 died in Africa and low income countries.

Finally, comparing the R-squares in both Model 2 and Model 3, the proportion of the total variation in child survival score explained by the included variables in Model 3 is $31.3 \%$, compare to just $4.1 \%$ in model 2 . Thus, the IV model to examine the linkage between household food security and child survival provides a better fit for the data.

\section{CONCLUSION}

Reducing the risk of food insecurity is a major challenge facing a majority of households in Africa. A major aspect of this challenge relates to addressing long-term vulnerability to chronic malnutrition amongst children, which threaten child survival (WHO, 2018). The socioeconomic circumstances of the household may affect both the quantity (affordability and availability) as well as the quality of food intake, especially the calorie intake and nutrition intensity of the food intake. For mothers, child survival may be dependent on the nutrition status, which in turn is a function of 
household food security. This study has examined the possible relationship between household food security, child nutrition status, and child survival, using a representative sample of women of child-bearing age (15-19 years). Largely because of the multidimensional nature of these outcomes, as each of them was measured from several dimensions, using several variables, composite measures or indexes were derived based on the response options in the data. This approach solved the multiple inference problem often encountered in this type of studying.

Food security score derived for the individual respondents suggests that the households in the sample were modestly food secured. Whilst about half of them were below the average score, the remaining half were above the average score. Based on the response of the majority of the respondents, it is not the case that they do not have enough to eat in the household, the nature of food insecurity is that they have enough but not always for all kinds of foods they want to eat. Hence, this manifests in the form of eating less balanced meals rather than going hungry. However, they often cope by eating less preferred food, rather than skipping meals altogether or go begging for food.

Secondly, the respondents scored high on the nutrition status index. Evidence from the nutrition status score showed that the respondents were generally well informed about nutrition. This was expected as they were largely educated women. They gave breast-milk when it became necessary at child birth. They were familiar with nutrition adverts through radio and television. However, having information and knowledge about nutrition intensity of food does not mean that the individual has the resources to purchase them. For example, despite the overwhelming majority that reported being familiar with food nutrition adverts, only about a third were eating nutrition intense food such as fruit and vegetables, or white/Irish potatoes. Indeed, nutrition intense food tends to be relatively more expensive than less nutritious food. It is often heard from people that they would like to eat healthier food but they could not afford to (e.g. Bandt, 2016). Therefore, familiarity does not translate into affordability.

Moreover, respondents appear to perform modestly on child survival index. They undertook activities that are more likely to enhance child survival than constraining it. These include attending their appointed antenatal days before delivery, adherence to recommended dietary intake during pregnancy, and giving breast-milk to the new born immediately after birth. Even though over half of the respondents reported that their child was ill within six months, the nature of the illness was mainly malaria or fever, which is less likely to be food related, and they sought medical attention from a health care facility. Put in perspective, the findings were consistent with previous findings, except that the present study offers an additional insight into the possible dimensions of the relationship between the socioeconomic circumstances of the individual, household food security, nutrition status, and child survival.

Finally, this study consists of limitations. Firstly, it was difficult to obtain the actual food consumption behaviour of the households surveyed in the study. This limits the extent to which causality can be assumed for the results. Food consumption data obtained from household food diaries and associated calories will improve the study greatly, particularly in linking nutrition status of household food consumption behaviour. Secondly, understanding the share of income expended on food would be consistent in capturing the substitution effect of income on food, which will provide a better understanding of the effect of income on household food security. This and other limitations could be addressed in future studies.

\section{POLICY RECOMMENDATIONS}

A key message from the present study is that improvement in household food security will also improve child health (survival), through its positive effect on nutrition status. It should be noted 
also that child survival is not only about improving nutrition status in the household or improving household food security, but also activities that mothers undertake to enhance child survival. Hence, it is recommended that women of child bearing age should be targeted for education and information on activities that enhance child survival. These include

i. It is important that pregnant women are encouraged to attend appointed antenatal days before delivery, during which any discrepancies about the pregnancy could be detected and addressed.

ii. It is equally important that mothers adhere to recommended dietary intakes when they are pregnant. Adherence will improve their nutrition status, hence healthy child. However, the extent to which they will adhere to any recommended dietary intakes is largely dependent on the resources at their disposal. It is clear that nutrition intense food tends to be more expensive than less healthy food. Therefore, a food bank intervention may be implemented where nutrition intense food is given to pregnant women on their antenatal appointment days. Not only will this improve their nutrition status, but also improve breast-feeding behaviour, and use of health care facilities during and after birth up to a year. Breast-feeding behaviour of mothers will remain poor as much as the mothers themselves do not eat healthy food. The design and implementation of the food bank intervention are beyond this study.

iii. Pregnant women should be encouraged to give birth in a health care facility to prevent premature births or complications at child birth.

iv. Improved breast-feeding behaviour of mothers. After birth, new mothers are often guided on the importance of breast-feeding. However, they do not always follow these guidelines largely because of their poor socioeconomic circumstances, including working conditions. Policies that improve the situation of nursing mothers should be implemented.

Funding: TETFUND provides funds for the study.

Competing Interests: Author declares that s/he has no conflict of interest with respect to this article.

Contributors/Acknowledgement: Author thanks to Dr. Damilola Olajide and Mr. Abatan Sunday Matthew for their comments and suggestions.

Views and opinions expressed in this study are the views and opinions of the authors, Asian Journal of Agriculture and Rural Development shall not be responsible or answerable for any loss, damage or liability etc. caused in relation to/arising out of the use of the content.

\section{References}

Abubakar, N., Atiku, M. K., Alhasan, A. J., Muhammed, I. Y., Garba, R. M., \& Gwarzo, G. D. (2017). An assessment of micronutrient deficiency: a comparative study of children with protein-energy malnutrition and apparently healthy controls in Kano, Northern Nigeria. Tropical Journal of Medical Research, 20(1), 61-65. doi.org/10.4103/1119-0388.198124.

Akindola, R. B., \& Ehinomen, C. O. (2017). Military incursion, tribalism and poor governance: the consequences for development in Nigeria. Meditaranian Journal of Social Sciences, 8(5), 151-157. doi.org/10.1515/mjss-2017-0033.

Aliber, M. (2009). Exploring statistics South Africa's national household surveys as analyzing vulnerability to food security. WIDER Research Paper 2006/119. Helsinki: United Nations University-World Institute for Development Economics Research (UNU-WIDER). Pp 65.

Andohol, J. (2012). Nigeria's food security programs: implications for MDG's Goal of Extreme Hunger Eradication. International Journal of Business and Social Science, 3(9), 112- 125.

Bandt, C. (2016). Economic constraints on taste formation and the true cost of healthy eating. Social Science and Medicine, 148, 34-41. doi.org/10.1016/j.socscimed.2015.11.025. 
Barrett, C. B., \& Lentz, E. C. (2010). Food insecurity, in oxford research encyclopaedia of international studies. Oxford University Press. United Kingdom.

Chaudhary, N., Raut, A. V., \& Sigh, A. R. (2016). Faulty feeding practices in children less than 2 years of age and their association with nutritional status: A study from a rural medical college in Central India. International Journal of Advanced Medical and Health Research, 3(2), 78-84. doi.org/10.4103/2349-4220.195943.

Chilton, M., Chyatte, M. R., \& Breaux, J. (2007). The negative effects of poverty \& food insecurity on child development. The Indian Journal of Medical Research, 126(4), 262-272.

Compton, J., Wiggings, S., \& Keats, S. (2010). Impact of the global food crisis on the poor: what is the evidence? A report by Overseas Development Institute, 111 Westminster Bridge Road London SE1 7JD UK.

Cordeiro, L., \& Lamstein, S. A. (2007). Household food security and the nutritional status of rural Tanzanian adolescents. Doctoral dissertation, Doctoral Thesis. Friedman School of Nutrition Science and Policy, Tufts University. Boston, USA.

Drammeh, W., Hamid, N., \& Rohana, A. J. (2019). Determinants of household food insecurity and its association with child malnutrition in Sub-Saharan Africa: a review of the literature. Current Research in Nutrition and Food Science, 7(3), 610-623. doi.org/10.12944/crnfsj.7.3.02.

Erhabor, A. G., \& Erhabor, I. N. (2016). Promoting food bank as a way of ensuring food security in Nigeria. GIDA, 41(3), 123-129.

FAO (1996). Participatory rural appraisal on household food security and nutrition, Kano State. Summary Report. FAO/TCP/NIR/4555 (T). Rome.

Food and Agricultural Organisation (FAO) (2008). The state of food and agriculture. Food and Agricultural Organization of the United Nations, Viale delle Terme di Caracalla 00153 Rome, Italy.

GPF - Global Policy Forum (2008). The effect of the food crisis on women and their families. Retrieved from https://www.globalpolicy.org/social-and-economic-policy/worldhunger/general-analysis-on-hunger/46209.html .

Hani, K. A. (2011). Diet for breastfeeding mothers - myths and facts about nutrition during lactation. Journal of Human Growth and Development, 21(3), 769-781.

Harttgen, K., \& Klasen, S. (2010). A household-based human development index. Proceedings of the German Development Economics Conference, Hannover 2010, No. 30 Provided in Cooperation with Research Committee on Development Economics (AEL), German Economic Association.

Ijarotimi, O. S., \& Odeyemi, A. O. (2011). Prevalence of food insecurity among rural communities and its effects on nutritional status of children (8-15 years) in Ondo State, Nigeria. Journal of Medicine and Medical Sciences, 3(1), 5-15.

ILO - International Labour Organisation (2006). International labour conference: maritime labour convention, 2006. Retrieved from file:///C:/Users/TOSHIBA/Downloads/wcms_090250.pdf

Jyoti, D. F., Frongillo, E. A., \& Jones, S. J. (2005). Food insecurity affects school children's academic performance, weight gain, and social skills. The Journal of Nutrition, 135(12), 2831-2839.

Katarzyna, L. (2019). Diet for breastfeeding mothers: myths and facts about nutrition during lactation. Polish Nursing / Pielegniarstwo, 73(3), 312-317.

McMahon, W. W. (2009). Higher learning, greater good: The private and social benefits of higher education (the private \& social benefits of higher education). Baltimore: The John Hopkins University Press.

Mosley, W. H., \& Chen, L. C. (1984). An analytical framework for the study of child survival in developing countries. Population and Development Review, 10(0), 25-45. doi.org/10.2307/2807954.

NBS - National Bureau of Statistic (2010). Nigeria - demographic and health survey. 2003, Fourth Round. https://www.nigerianstat.gov.ng/nada/index.php/catalog/26. 
NPC - National Population Commission (2006). Federal Republic of Nigeria Official Gazette, 96(2). Government of Nigeria.

Ojo, E. O., \& Adebayo, P. F. (2012). Food security in Nigeria: an overview. European Journal of Sustainable Development, 1(2), 199-222. doi.org/10.14207/ejsd.2012.v1n2p199.

Ojogho, O. (2010). Determinants of food insecurity among arable farmers in Edo state, Nigeria. Agricultural Journal, 5(3), 151-156. doi.org/10.3923/aj.2010.151.156.

Olagunju, F. I., Oke, J. T. O., Babatunde, R. O., \& Ajiboye, A. (2012). Determinants of food insecurity in Ogbomosho metropolis of Oyo state, Nigeria. PAT June, 8(1), 11-124.

Omonona, B. T., \& Agoi, G. A. (2007). An analysis of food security situation among Nigerian urban households: evidence from Lagos state, Nigeria. Journal of Central European Agriculture, 8(3), 397-406.

Psacharopoulos, G., \& Woodhall, M. (1997). Education for development: An analysis of investment choice. New York: Oxford University Press.

Romer-Lovendal, C., \& Knowles, M. (2006). A framework for analysing vulnerability to food security. Research Paper No. 2006/119. United Nations University, Japan.

Shinsugi, C., Matsumura, M., Karama, M., Tanaka, J., Changoma., M., \& Kaneko, S. (2015). Factors associated with stunting among children according to the level of food insecurity in the household: a cross-sectional study in a rural community of Southeastern Kenya. BMC Public Health, 15, 441.

Thomas, D., \& Strauss, J. (1997). Health and wages: evidence on men and women in urban Brazil. Journal of Econometrics, 77(1), 159-185. doi.org/10.1016/s0304-4076(96)01811-8.

Vandevijvere, S., Chow, C. C., Hall, K. D., Umali, E., \& Swinburn B. A. (2015). Increased food energy supply as a major driver of the obesity epidemic: a global analysis. Bull World Health Organ, 93, 446-456. doi.org/10.2471/blt.14.150565.

WHO - World Health Organisation (2018). Infant and young child feeding. Retrieved from https://www.who.int/news-room/fact-sheets/detail/infant-and-young-child-feeding. 